\title{
PERLINDUNGAN HUKUM SENI BATIK KARAWANG DITINJAU MELALUI UNDANG-UNDANG NOMOR 28 TAHUN 2014 TENTANG HAK CIPTA
}

\author{
${ }^{1}$ Munirotul Qolbiyah, ${ }^{2}$ Devi Siti Hamzah Marpaung
}

Program Studi Ilmu Hukum, Universitas Singaperbangsa Karawang, Kab. Karawang, Jawa Barat. Email :munirotulq@gmail.com

\section{Info Artikel:}

| Submission : 8 November 2020

| Revissions : 18 November 2020

: 29 November 2020

| Accepted : 11 Desember 2020

: 10 Desember 2020

\begin{abstract}
Abstrack
This writing aims to find out how the development of batik in Karawang Regency as well as legal protection of the batik copyright typical of Karawang Regency with the provisions contained in Law Number 28 of 2014 concerning Copyright. Batik art is a technique of drawing on cloth and utilizing wax and canting as materials and tools to make it, batik is one of the works of art that requires high intellectuality in its creation. Legal protection of batik copyright is needed to avoid things that will be detrimental to the creator and copyright holder. The approach method used in this research is juridical empirical, which is research based on legislation and also using research based on facts, realities and problems in the field. The empirical juridical approach is a study that examines legal regulations, namely Law Number 28 of 2014 concerning Copyright, which is then linked with data from research research on batik typical of Karawang Regency.
\end{abstract}

Keywords: Protection; Copyright; Batik; Art. 


\section{A. PENDAHULUAN}

Indonesia dikenal memiliki budaya yang sangat beragam, keberagaman dan kekhasan budaya dari setiap suku bangsa merupakan aset yang tidak terhitung jumlahnya. Warisan budaya tersebut merupakan peninggalan nenek moyang menjadi beragam dan mempunyai ciri khas tersendiri pada setiap kebudayaan yang ada di Indonesia, warisan budaya sendiri dapat diartikan sebagai jati diri suatu bangsa dengan kata lain martabat suatu bangsa ditentukan oleh kebudayaannya, masyarakat seharusnya turut serta dalam menjaga dan melestarikan warisan budaya bukan hanya sebatas mengagumi.

Warisan budaya tersebut sepatutnya dijaga sebagai jati diri bangsa, salah satunya dengan mengeluarkan peraturan perundang-undangan yang bertujuan untuk mengatur perlindungan warisan budaya agar terjamin oleh hukum keberadaanya. Hak atas Kekayaan Intelektual (HAKI/KI) merupakan hak atas kekayaan yang lahir dari kemampuan intelektual manusia, KI sendiri merupakan hak yang diberikan kepada orangorang atas hasil buah pikiran pencipta seperti yang tulisan, kreasi, artistik, penamaan, dan desain dalam waktu tertentu.

Seiring dengan perkembangan waktu muncul berbagai macam HAKI yang termuat di dalam perjanjian internasional tentang aspek-aspek perdagangan dari $\mathrm{KI}$ (Agreement Trade Related aspect of Intellectual Property Rights atau TRIPs Agreement) sebagai bagian dari pembentukan Organisasi Perdagangan Dunia (World Trade Organization), di dalam Pasal 1.2 menyatakan bahwa HAKI terdiri dari: a) Hak Cipta (Copyright) dan hak-hak yang terkait lainnya, b) Merek (Mark), c) Indikasi Geografis (Geographical Indication), d) Desain Produksi Industri (Industrial Design), e) Paten (Patent), f) Rangkaian Elektronika Terpadu (Layout Design of Integrated Circuit), g) Perlindungan Rahasia Dagang (Undisclosed Information/Trade Secret), dan $\mathrm{h}$ ) Pengendalian terhadap Praktik Persaingan Curang/Tidak Sehat (Repression Unfair Competition Practices) ${ }^{1}$.

Menurut WIPO atau The World Intellectual Property Organization secara garis besar HAKI meliputi dua cabang, yaitu a) Hak Cipta atau Copyright dan b) Hak atas Kekayaan Industri atau Industrial Property Right (yang terdiri dari Paten (Paten), Merek (Mark), Desain Produksi Industri (Industrial Design), dan Penanggulangan Praktik Persaingan Curang (Repression of Unfair Competition Practices)). Selain mengatur tentang peraturan perundang-undangannya, KI dalam ilmu hukum dimasukkan ke dalam golongan benda yang mempunyai objek benda intelektual yaitu benda tidak berwujud. ${ }^{2}$

\footnotetext{
${ }^{1}$ Devi Rahayu, "Perlindungan Hukum Terhadap Hak Cipta Motif Batik Tanjungbumi Madura”, Jurnal Mimbar Hukum, Vol 23, Nomor 1, Februari 2011, hlm. 116

${ }^{2}$ Ridwan Khairandy, Pengantar Hukum Dagang, (Yogyakarta: UII Press, 2006), hlm. 226
} 
Indonesia sendiri telah membuat berbagai kebijakan KI antara lain dibidang peraturan perundang-undangan kekayaan intelektual dan upaya peningkatan kesadaran masyarakat terhadap HAKI. Saat ini telah berlaku Undang-Undang Nomor 29 Tahun 2000 tentang Perlindungan Varietas Tanaman, Undang-Undang Nomor 30 Tahun 2000 tentang Rahasia Dagang, Undang-Undang Nomor 31 Tahun 2000 tentang Desain Industri, Undang-Undang Nomor 32 Tahun 2000 tentang Desain Tata Letak Sirkuit Terpadu, Undang-Undang Nomor 13 Tahun 2016 tentang Paten, Undang-Undang Nomor 20 Tahun 2016 tentang Merek dan Indikasi Geografis, dan Undang-Undang Nomor 28 Tahun 2014 tentang Hak Cipta.

Hak Cipta (Copyright) merupakan salah satu bidang KI yang mempunyai arti sebagai hak ekslusif bagi pencipta maupun penerima hak untuk mengumumkan atau memperbanyak ciptaannya atau memberi izin untuk itu dengan tidak mengurangi pembatasan-pembatasan menurut peraturan perundang-undangan yang berlaku. Di dalam Undang-Undang Nomor 28 Tahun 2014 tentang Hak Cipta membawa kemajuan baru khususnya di bagian perlindungan hak cipta tersebut yang meliputi perlindungan terhadap buku, program komputer, sampul karya tulis yang diterbitkan, ceramah, kuliah, pidato, lagu atau musik dengan atau tanpa teks, drama, tari, koreografi, pewayangan dan pantomim, seni rupa, arsitektur, seni batik, fotografi, sinematografi, terjemahan, tafsir, dan karya lain hasil dari pengalihwujudan. Dari sekian banyak ciptaan yang dilindungi undang-undang, penulis mengkhususkan membahas tentang hak cipta atas seni batik, yaitu motif batik dari Kabupaten Karawang.

Batik merupakan salah satu warisan budaya bagi bangsa Indonesia dan juga merupakan suatu identitas bangsa, pada mulanya batik diciptakan secara konvensional dengan ciri khas bangsa Indonesia yang dilindungi undang-undang tersendiri yaitu undang-undang hak cipta. Batik mendapat perlindungan karena mempunyai nilai seni baik pada ciptaan motif atau gambar maupun komposisi warnanya. Setiap daerah di Indonesia mempunyai ciri khas tersendiri tentang batik dan ciri khas tersebut dapat dilihat dari segi warna atau corak gambar atau pola. ${ }^{3}$

Pada tanggal 2 Oktober 2009 merupakan hari yang bersejarah di mana pada tanggal tersebut batik Indonesia mendapat sebuah pengakuan dan penghargaan oleh sebuah organisasi internasional dibawah PBB yakni UNESCO (United Nations Educational, Scientific and Cultural Organization), pengakuan dan penghargaan tersebut adalah batik Indonesia secara resmi oleh UNESCO dengan dimasukkan ke dalam daftar representatif sebagai budaya tak benda warisan manusia. Presiden Republik Indonesia yaitu bapak Susilo Bambang Yudhoyono meminta kepada seluruh masyarakat Indonesia setiap tanggal 2 Oktober untuk memakai batik sebagai bentuk rasa syukur atas diakuinya batik oleh UNESCO. Tidak hanya itu, tanggal 2 Oktober 2009 ditetapkan sebagai hari

${ }^{3}$ Linsey Tim, et.all, Hak Kekayaan Intelektual: Suatu Pengantar, (Bandung: PT. Alumni, 2013), hlm. 101 
batik Nasional yang dimuat di dalam Keputusan Presiden Nomor 33 Tahun 2009 Tentang Hari Batik Nasional.

Batik dianggap sebagai karya seni turun temurun yang harus dijaga kelestariannya, setiap motif batik yang diciptakan di setiap daerah akan berbeda dengan daerah lainnya, hal tersebut berkaitan erat dengan keadaan wilayah pencipta batik. Motif pada batik seringkali dihubungkan dengan kehidupan yang terjadi pada pada suatu daerah tertentu yang bermakna khusus pada budaya mereka. Begitu pula batik dari Kabupaten Karawang, memiliki nilai-nilai historis dan estetika Kabupaten Karawang yang keberadaannya tidak sesederhana yang kita pikirkan, terdapat jalan panjang yang berliku sehingga terdapat batik khas Kabupaten Karawang seperti sekarang ini.

Kabupaten Karawang terdapat sejarah tentang batik sejak lama, pada tahun 1928 dengan nama batik Tarawang atau batik Tarum pernah diikut sertakan di dalam pameran Batik Jawa di Amsterdam, dan batik Tarawang ini dibuat oleh keluarga Tan Tjeng Kwang yang menetap di Rengasdengklok sekitar tahun 1880, batik Tarawang sendiri telah diproduksi oleh Ny. Vincen Hegen yang merupakan istri dari pelukis Raden Saleh. ${ }^{4}$ Selanjutnya, setelah sekian lama berlalu batik khas Kabupaten Karawang kembali muncul dengan kehadiran Ibu Hj. Istiqomah sebagai pendiri dari Bale Batik Taza.

Menurut hasil penelitian yang dilakukan penulis, bahwa Ibu $\mathrm{Hj}$. Istiqomah dan putranya yaitu Bapak Taufiq telah mendaftarkan hasil ciptaannya pada Kementerian Hukum dan HAM, namun tetap saja pada praktiknya masih ada beberapa orang yang menjiplak batik hasil ciptaan Ibu $\mathrm{Hj}$. Istiqomah atau Bapak Taufiq. Selain permasalahan terjadi pada hak cipta, sekarang ini banyak sekali yang tidak mengetahui keberadaan batik khas Kabupaten Karawang, maka dari itu penulis ingin memperkenalkan tentang batik khas Karawang kepada seluruh masyarakat Indonesia. Dari uraian diatas menjadi landasan penulis dalam melaksanakan penelitian tentang bagaimana perkembangan batik khas Kabupaten Karawang dan bagaimana perlindungan hak cipta atas batik khas Kabupaten Karawang.

Konsepsi perlindungan dalam penelitian Andhini dan Arifin ${ }^{5}$ dikonsepsi pada bentuk perlindungan yuridis yang menunjukkan suatu peraturan hukum sebagai alat perlindungan. Perlindungan hukum dalam penjelasan Aji Mulyana dalam Fuqoha, dkk. ${ }^{6}$, diartikan sebagai bentuk perlindungan terhadap hak setiap orang dari perlakuan yang

\footnotetext{
4 Sabrina Santi, "Sejarah Batik Karawang”, dalam Naskah Online/Website (April, 2018), https://infobatik.id/sejarah-batik-karawang/ . (diakses pada tanggal 15 November 2020, pukul 09. 13 WIB)

5 Alycia Sandra Dina Andhini and Ridwan Arifin, "Analisis Perlindungan Hukum Terhadap Tindak Kekerasan Pada Anak Di Indonesia," Ajudikasi: Jurnal Ilmu Hukum Vol. 3, No. 1 (2019): 41-52, https://doi.org/10.30656/ajudikasi.v3i1.992.

${ }^{6}$ Fuqoha Fuqoha, Indrianti Azhar Firdausi, and Arga Eka Sanjaya, "Perlindungan Hukum Terhadap Intervensi Pemberitaan Dalam Kerangka Kemerdekaan Pers Nasional," Ajudikasi : Jurnal Ilmu Hukum Vol. 3, No. 1 (2019): 75, https://doi.org/10.30656/ajudikasi.v3i1.1436.
} 
dapat menimbulkan kerugian melalui hukum dan/atau perundang-undangan. Oleh karena itu, perlindungan hukum terhadap seni batik menjadi suatu hal yang harus diperhatikan oleh pemerintah. Namun demikian, pemahaman terhadap perlindungan hukum terhadap seni batik belum dapat dimaksimalkan oleh setiap pegiat seni batik. hal tersebut dapat berakibat pada kekhasan dan kepemilikan suatu karya seni batik di lingkungan nasional maupun internasional.

\section{B. METODE PENELITIAN}

Dalam menganalisis uraian permasalahan yang diteliti, penulis mendeskripsikan penelitian yang bersifat kualitatif yaitu berdasarkan data yang diperoleh kemudian dikaitkan dengan peraturan perundang-undangan dan berdasarkan penelitian di lapangan, untuk menemukan kebenaran yang berdasarkan logika keilmuan hukum yang nantinya akan ditarik sebuah kesimpulan. Metode pendekatan yang digunakan pada penelitian ini adalah yuridis empiris, yaitu penelitian yang didasarkan pada perundang-undangan dan juga menggunakan penelitian yang didasarkan pada fakta, realita dan permasalahan yang ada di lapangan. ${ }^{7}$ Yuridis empiris ini merupakan cara atau prosedur yang digunakan untuk memecahkan masalah penelitian dengan meneliti data sekunder terlebih dahulu untuk kemudian dilanjutkan dengan meneliti data primer yang ada di lapangan. Pendekatan yuridis empiris merupakan suatu penelitian yang meneliti peraturan hukum yaitu Undang-Undang Nomor 28 Tahun 2014 tentang Hak Cipta, yang kemudian dihubungkan dengan data hasil dari penelitian penelitian batik khas Kabupaten Karawang.

Adapun penelitian ini menggunakan data primer, data sekunder, dan data tersier. ${ }^{8}$ Untuk data primer yaitu data yang diperoleh langsung dari sumbernya, data ini diperoleh dengan wawancara secara langsung dengan pihak terkait yaitu pencipta dari batik Kabupaten Karawang yaitu Bapak Taufiq selaku anak dari Ibu $\mathrm{Hj}$. Istiqomah. Adapun data sekunder berupa bahan-bahan hukum seperti peraturan perundang-undangan, dan hukum. Sementara data tersier diperoleh dari majalah, internet, dan lain-lain yang terkait dengan masalah yang diteliti. Lokasi penelitian adalah di Kabupaten Karawang tepatnya di Bale Batik Taza beralamat di Jl. KH Ahmad Dahlan Nomor 20 Karawang Kulon (Belakang Masjid Agung Karawang) dengan dasar pertimbangan bahwa tempat tinggal informan kunci yaitu perajin batik adalah pusat penghasil batik khas Kabupaten Karawang. Penelitian ini dilakukan dengan cara mencari data secara langsung yang ada di Bale Batik Taza untuk mengungkap fakta kunci yang dipilih berdasarkan kriteria yang dianggap layak untuk memberikan keterangan.

\footnotetext{
${ }^{7}$ Soerjono Soekanto, Pengantar Penelitian Hukum, (Jakarta: Universitas Indonesia, 2006), hlm. 46

${ }^{8}$ Iqbal Hasan, Metode Penelitian Hukum dan Aplikasinya, (Bandung: Remaja, 2002), hlm. 35
} 
Cara mengumpulkan data yaitu dengan mengumpulkan data hukum, kemudian diklasifikasikan sesuai dengan permasalahan yang diangkat. Selain itu, melakukan proses tanya jawab dengan menanyakan secara langsung informasi kepada informan kunci dengan sistematik berlandaskan kepada tujuan penelitian. Adapun metode analisis data, yang pertama kali dilakukan adalah editing, yaitu memeriksa bahan dan data hukum untuk memastikan kelengkanpan, kejelasan makna, korelasi dan relevansinya. Kedua, mengklasifikasikan hasil wawancara, literatur, dokumen dan peraturan perundangundangan. Analisis data penelitian menggunakan metode deskriptif analitis yaitu dengan menuturkan dan menggambarkan fakta apa adanya sesuai dengan temuan pustaka. Dan kemudian dianalisis kembali dengan Undang-Undang Nomor 28 Tahun 2014 tentang Hak Cipta dan ditampilkan secara deskriptif.

\section{HASIL DAN PEMBAHASAN}

\section{Perkembangan Seni Batik Karawang}

Dalam khazanah kebudayaan di Indonesia, batik merupakan salah satu bentuk seni kuno. Batik berasal dari bahasa Jawa yaitu "amba" artinya tulis dan "nitik" artinya titik, maksudnya adalah kegiatan membatik diatas kain menggunakan canting yang ujungnya kecil memberi kesan "orang sedang menulis titik-titik". ${ }^{9}$ Meskipun kata batik berasal dari bahasa Jawa, namun asal dari batik sendiri masih menjadi misteri dan masih menjadi perdebatan sampai saat ini.

Kreativitas seni batik saat ini tidak hanya berkutat pada budaya lokal atau budaya Jawa saja, akan tetapi juga bertemu dengan budaya luar. Kebudayaan jawa yang bersentuhan dengan budaya lain seperti pada saat perdagangan dengan China, India dan Timur Tengah yang memberi warna tersendiri dan ragam pada motifnya.

Popularitas batik mulai meningkat pada akhir abad ke-18 atau awal abad ke-19 ditandai dengan munculnya batik cap dan hal tersebut menjadi awal dari era industrialisasi. Selain itu, sejak industrialisasi dan globalisasi yang memperkenalkan teknik otomatisasi, batik ini merupakan batik jenis baru yakni batik printing. Batik printing ini banyak mempengaruhi perkembangan batik ke arah industri karena prosesnya yang cepat dan harganya yang jauh lebih murah dibandingkan dengan batik tulis karena:

a. Batik tulis adalah kain yang dihias dengan motif batik menggunakan tangan, proses pembuatan batik tulis ini membutuhkan waktu kurang lebih 2-3 bulan.

\footnotetext{
${ }^{9}$ Iskandar dan Eny Kustiyah, "Batik Sebagai Identitas Kultural Bangsa Indonesia Di Era Globalisasi”, Jurnal Gema, Volume 52, Agustus 2016-Januari 2017, hlm. 2458
} 
b. Batik cap adalah kain yang dihias dengan motif batik yang terbentuk oleh cap yang biasanya terbuat dari tembaga, untuk proses pembuatan batik cap ini hanya memakan waktu kurang lebih 2-3 hari.

Sementara itu, perkembangan batik semakin cepat terbukti dengan setiap daerah di Indonesia yang memiliki motif batik sendiri bahkan di setiap daerahnya mempunyai kampung batik seperti Kampung Batik Trusmi di Cirebon, Kampoeng Batik Laweyan di Solo, Kampoeng Batik Kauman. Di Kabupaten Karawang sendiri, perkembangan batik sudah dimulai pada tahun 1928 batik Tarawang telah diikutsertakan di sebuah pameran Batik Jawa di Amsterdam, batik Tarawang sendiri dibuat oleh keluarga dari Tan Tjeng Kwat, dan diproduksi oleh Ny. Vincen Hegen yang merupakan istri dari seorang pelukis Raden Saleh. ${ }^{10}$

Seiring berjalannya waktu, batik Karawang kembali muncul ke khalayak ramai tepatnya pada tahun 2008, sosok Ibu $\mathrm{Hj}$. Istiqomah yang menjadi pelopor kebangkitan batik Karawang. Bermula dari beberapa tahun kebelakang, Ibu $\mathrm{Hj}$. Istiqomah yang sering berpindah-pindah tempat tinggal karena mengikuti dinas suami. Setelah pensiunnya sang suami, Ibu $\mathrm{Hj}$. Istiqomah selaku orang Karawang asli membuka toko bunga dengan nama "Taza Florist", berawal dari toko bunga yang sering mengikuti pameran-pameran dan melihat peserta pameran lain yang di stan nya sudah ada batik dengan hal itu maka Ibu Hj. Istiqomah akhirnya mulai mencoba untuk mendesain motif batik Karawang. hingga pada tahun 2011 mulai dibukanya Bale Batik Taza. ${ }^{11}$

Sampai sejauh ini, terhitung Bale Batik Taza sudah mempunyai 25 motif, dengan beberapa motif sudah didaftarkan hak cipta ke Kementerian Hukum dan HAM antara lain adalah motif Cigeuntis, motif Citarum, motif Goyang Karawang, motif Pare Sagedeng, motif Leuit, motif Citarum, motif Padi, dan motif Panen Raya. Dan beberapa motif yang menjadi favorit dari batik Karawang ini adalah motif Panen Raya, motif Citarum, motif Cigentis, dan motif Pare Sagedeng. Dari masa ke masa perkembangan batik Karawang mulai menyesuaikan dengan zaman, namun tetap masih berkaitan dengan kearifan lokal yang terkait dengan sosial dan budaya daerah Karawang. Motif batik Karawang tersusun dengan sangat beragam yang memiliki unsur simbolis filosofis. Makna kiasan yang ada di dalam batik khas Kabupaten Karawang:

a. Makna dari tumpal mengandung arti Ketuhanan Yang Maha Esa;

b. Makna dari bunga tarum atau bunga vidas merupakan bunga simbolik untuk agama Hindu Budha yang dibuat oleh pembatik Karawang;

c. Makna dari bulir padi dan lumbung padi merupakan lambang kemakmuran daerah Karawang;

10 Sabrina Santi, "Sejarah Batik Karawang”, dalam Naskah Online/Website (April, 2018), https://infobatik.id/sejarah-batik-karawang/ .(diakses pada tanggal 15 November 2020, pukul 09. 13 WIB)

${ }^{11}$ Hasil Wawancara dengan Bapak Taufiq, merupakan anak dari Ibu $\mathrm{Hj}$ Istiqomah. 
d. Makna dari ragam hias garis dan bidang geometri sebagai motif perlambangan yang dimiliki masyarakat suku buni sebagai masyarakat asli Karawang,

e. Makna dari garis gelombang laut sebagai lambang daerah partai memiliki laut.

Untuk makna motif batik Pare Sagedeng menunjukkan ciri khas dari Kabupaten Karawang sebagai Kota Lumbung Padi terbesar di Indonesia. ${ }^{12}$ Selain motif bati Pare Segendeng terdapat beberapa motif batik karawang yang menjadi cirri khas batik Kabupaten Karawang. Berikut macam-macam motif batik dari Kabupaten Karawang :

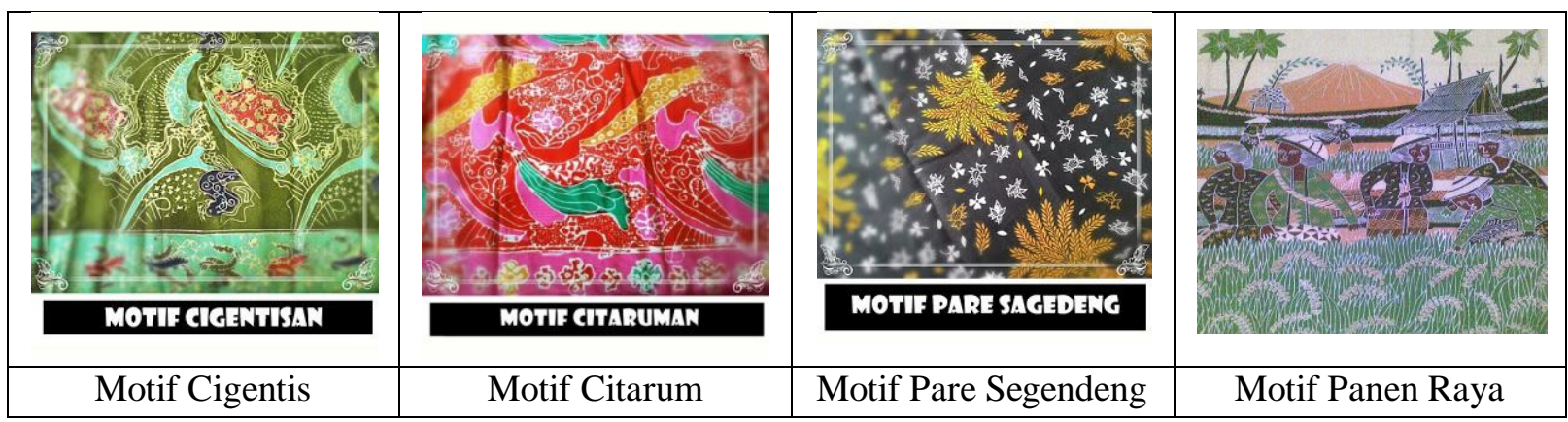

Gambar : Motif Batik Karawang

Kabupaten Karawang serta ada makna dan filosofinya tentang motif dari Pare Sagedeng. Saat ini batik sudah tidak diidentifikasikan sebagai pakaian formal yang digunakan oleh orang tua, karena yang terjadi saat ini batik dapat digunakan secara bebas baik untuk acara formal maupun sehari-hari. Hal ini berkaitan dengan mode serta kain batik itu sendiri sehingga dapat dinikmati oleh seluruh kalangan usia. ${ }^{13}$ Menurut Bapak Taufiq, Bale Batik Taza berkolaborasi dengan acara pemilihan Putra Putri Batik Karawang tahun 2019, lomba menggambar dan mewarnai batik untuk anak-anak, serta kegiatan-kegiatan lain dalam rangka pelaksanaan Hari Batik Nasional. $^{14}$

\section{Perlindungan Hak Cipta Seni Batik Karawang}

Hak cipta merupakan bagian dari cabang dari HKI yang penting untuk dipahami oleh semua masyarakat. Sehingga perlindungan hak cipta menjadi isu yang penting dalam menghadapi era ekonomi pasar bebas. Indonesia sebagai negara yang produktif dalam karya cipta, tentunya wajib melindungi warga negaranya dari usaha

\footnotetext{
${ }^{12}$ Dedi Satria, "Batik Taza Khas Karawang, Kedepankan Motif Kearifan Lokal”, dalam Naskah Online/Website (Oktober 2019), https://www.pasundanekspress.co/jabar/karawang/batik-taza-khas-karawang-kedepankanmotif-kearifan-lokal/ (diakses pada tanggal 15 November 2020 pukul $15.00 \mathrm{WIB}$ )

13 Alicia Amaris Trixie, "Filosofi Motif Batik Identitas Bangsa Indonesia", Jurnal Folio, Volume 1 Nomor 1, Februari 2020, hlm. 7

${ }^{14}$ Hasil Wawancara dengan Bapak Taufiq, merupakan anak dari Ibu $\mathrm{Hj}$. Istiqomah.
} 
plagiarisme dan piracy, melalui perlindungan hak cipta sebagaimana diatur dalam undang-undang hak cipta menjadi upaya pemerintah dalam memberikan perlindungan hukum bagi para pencipta. ${ }^{15}$

Hak cipta adalah hak yang langsung dimiliki seseorang setelah ia berhasil mewujudkan sebuah kreasi yang ada di dalam pikirannya dapat berupa suatu ide-ide, gagasan maupun barang. Tetapi, pada saat ini semakin banyak problematika mengenai hak cipta, maraknya pembajakan di Indonesia terhadap HKI membuat para produsen dan para pemegang HAKI banyak dirugikan dalam kenyataannya produk-produk bajakan tersebut malah banyak digemari bahkan dicari oleh sebagian besar masyarakat Indonesia. Undang-Undang Nomor 28 Tahun 2014 tentang Hak Cipta memberikan definisi bahwa hak cipta adalah hak eksklusif pencipta yang timbul secara otomatis berdasarkan deklaratif setelah suatu penciptaan yang diwujudkan ke dalam bentuk nyata tanpa mengurangi pembatasan sesuai dengan ketentuan peraturan perundangundangan.

Hak cipta adalah hak eksklusif bagi pencipta maupun penerima hak untuk mengumumkan atau memperbanyak ciptaannya atau memberi izin untuk itu dengan tidak mengurangi pembatasan-pembatasan menurut peraturan perundang-undangan yang berlaku, hak ini memberikan perlindungan khusus kepada pencipta atas karyanya dalam lapangan ilmu, sastra dan seni, perlindungan hak cipta bukan karena pendaftarannya melainkan karena pengumumannya untuk pertama kali. ${ }^{16}$

Syarat yang harus ada dalam perlindungan hukum dibidang Hak Cipta adalah asas originalitas (keaslian). Keaslian ini tidak bisa dilakukan seperti halnya novelty (kebaruan) yang ada dalam paten, karena prinsip originalitas adalah tidak meniru ciptaan lain, jadi hanya dapat dibuktikan dengan suatu pembuktian oleh penciptanya. ${ }^{17}$ Beberapa Konvensi Internasional mengenai hak cipta diantaranya adalah:

a. Berne Convention, dilaksanakan pada tahun 1886 dan telah direvisi di Paris pada tahun 1971, konvensi ini mengatur tentang lingkup perlindungan hak cipta, kepemilikan hak cipta, hak-hak pencipta, jangka waktu perlindungan hak cipta dan pengecualian-pengecualian hak cipta. Terdapat tiga prinsip dasar pada konvensi ini yaitu: prinsip national treatment yaitu perlindungan yang sama bagi karya cipta warga sendiri maupun warga negara asing peserta konvensi, prinsip automatically protection yaitu pemanfaatan dan perlindungan tanpa adanya pendaftaran secara formal, dan prinsip independent protection

\footnotetext{
${ }^{15}$ Khorul Hidayah, Hukum HKI: Hak Kekayaan Intelektual, (Malang: Setara Press, 2017), hlm. 28

${ }^{16}$ Abdul Atsar, Mengenal Lebih Dekat Hukum Hak Kekayaan Intelektual, (Yogyakarta: deepublish, 2019), hlm.34

${ }^{17}$ Rindia Fanny Kusumaningtyas, "Perlindungan Hak Cipta Atas Motif Batik Sebagai Warisan Budaya Bangsa", dalam Jurnal Online, Januari 2014, hlm. 95
} 
yaitu pemanfaatan dan perlindungan ciptaan di negara asing tidak bergantung pada perlindungan di negara asal ciptaan dilindungi.

b. Universal Copyrights Convention, konvensi ini dilaksanakan pada tahun 1952 dengan tujuan untuk memfasilitasi negara yang belum mau bergabung dengan Berne Convention. Pada konvensi ini juga terdapat prinsip dasar yang sama dengan yang terdapat di dalam Berne Convention namun konvensi ini memberikan syarat yang lunak terhadap pengaturan pengakuan hak moral.

c. Rome Convention, konvensi ini dilaksanakan pada tahun 1971 dan konvensi ini dibentuk karena adanya perkembangan teknologi rekaman suara yang membuka peluang penggandaan dengan cara mudah, dan dengan kualitas yang sama.

d. Trade Related Aspect of Intellectual Property Rights (TRIPs) merupakan lampiran dari persetujuan pembentukan organisasi perdagangan dunia (WTO), di dalam TRIPs ini memuat aturan-aturan dasar yang berkaitan dengan hak cipta meliputi hak cipta dan hak-hak terkait, perlindungan program komputer, hak persewaan, jangka waktu perlindungan, pengecualian, perlindungan terhadap artis penampil, produser rekaman suara dan organisasi penyiaran.

Peraturan perundang-undangan mengenai hak cipta di Indonesia mengalami beberapa kali perubahan dan penggantian yaitu Undang-Undang Nomor 8 Tahun 1982 yang diperbaharui dengan Undang-Undang Nomor 17 Tahun 1987, Undang-Undang Nomor 12 Tahun 1997, Undang-Undang Nomor 19 Tahun 2002, dan saat ini UndangUndang Nomor 28 Tahun 2014.

Pemegang Hak Cipta adalah seorang atau beberapa orang yang secara sendiri atau bersama-sama menghasilkan suatu ciptaan yang bersifat khas dan pribadi (Pasal 1 angka 2 Undang-Undang Nomor 28 Tahun 2014 tentang Hak Cipta). Ciptaan adalah hasil karya setiap pencipta dalam bentuk yang khas dan menunjukkan keasliannya dalam lapangan ilmu pengetahuan, seni dan sastra. ${ }^{18}$ Menurut Pasal 1 angka 3 Undang-Undang Nomor 28 Tahun 2014 tentang Hak Cipta, ciptaan adalah setiap hasil karya cipta di bidang ilmu pengetahuan, seni, dan sastra yang dihasilkan atau inspirasi, kemampuan, pikiran, imajinasi, kecekatan, keterampilan, atau keahlian yang diekspresikan dalam bentuk nyata.

Undang-Undang Nomor 28 Tahun 2014 tentang Hak Cipta menjelaskan mengenai barang-barang yang dilindungi terdapat pada Pasal 40 ayat (1) meliputi: buku, pamflet, dan semua hasil karya tulis lainnya; ceramah, kuliah, pidato, dan ciptaan sejenis alat peraga yang dibuat untuk kepentingan pendidikan dan pengetahuan; lagu atau musik dengan atau tanpa teks, drama, drama musikal, tari,

${ }^{18}$ Abdul Atsar, op.Cit, hlm.36 
koreografi, pewayangan, pantomim; karya seni rupa dalam segala bentuk seperti lukisan, gambar, ukiran, kaligrafi, seni pahat, patung atau kolase; karya arsitektur, peta; dan karya seni batik atau seni motif lain. Namun, di dalam Undang-Undang Nomor 28 Tahun 2014 tentang Hak Cipta juga dijelaskan bahwa terdapat karya yang tidak dapat dilindungi oleh hak cipta, seperti yang tertera di Pasal 41 dan Pasal 42.

Batik termasuk dalam ciptaan yang dilindungi oleh Undang-Undang Nomor 28 Tahun 2014 Tentang Hak Cipta. Seni batik merupakan sebuah teknik menggambar di atas kain dan memanfaatkan lilin dan canting sebagai bahan dan alat untuk membuatnya. Menurut Nusjirwan Tirtaamidjaja seni batik adalah teknik menghias kain atau tekstil dengan menggunakan lilin dalam proses pencelupan warna, yang semua proses tersebut menggunakan tangan. Afifa Syakur menyatakan batik adalah serentang warna meliputi proses pemalaman (lilin), pencelupan (pewarnaan) dan pelorotan (pemanasan), hingga menghasilkan motif yang halus yang semuanya ini memerlukan ketelitian yang tinggi. ${ }^{19}$

Berdasarkan uraian tentang pengertian batik, dapat disimpulkan bahwa batik khas Kabupaten Karawang merupakan kain bergambar yang dibuat dengan menuliskan malam hingga membentuk suatu motif yang menggambarkan antara masyarakat kebudayaan-kebudayaan ataupun ciri khas dari Kabupaten Karawang seperti Padi yang menggambarkan bahwa Kabupaten Karawang merupakan penghasil padi dengan julukan "lumbung padi". Secara definitif, penciptaan motif batik khas Kabupaten Karawang mengandung beberapa unsur yaitu pencipta, ciptaan, motif, unsur seni dan originalitas. Penjelasan mengenai unsur-unsur tersebut terdapat dalam Pasal 1 ayat (1) tentang hak cipta, Pasal 1 ayat (2) tentang pencipta, dan Pasal 1 ayat (3) tentang ciptaan.

Selain itu, motif batik khas Kabupaten Karawang yang dibuat oleh pengrajin batik, baik perorangan maupun bersama-sama merupakan salah satu bentuk ciptaan, dimana pengrajin batik tersebut dinyatakan sebagai pencipta sekaligus pemegang Hak Cipta dari hasil karya motif batik tersebut. Motif batik khas Kabupaten Karawang merupakan hasil kreasi dan inovasi dari pengrajin batik saat ini merupakan batik kontemporer yang dilindungi menurut Pasal 40 ayat (1) huruf j Undang-undang No. 28 Tahun 2014 tentang Hak Cipta. Karya tersebut dilindungi karena mempunyai nilai seni, baik dalam kaitannya dengan gambar, corak, maupun komposisi warna. Dengan demikian, seni batik termasuk di dalamnya batik khas Kabupaten Karawang telah mendapat perlindungan hukum di dalam hukum positif di Indonesia.

Untuk masa berlaku dari hak cipta batik sendiri terdapat di dalam Pasal 58 Undang-Undang Nomor 28 Tahun 2014, bahwa seni batik berlaku selama hidup

${ }^{19}$ Sulasno dan Mia Mukaromah, "Perlindungan Hukum Terhadap Hak Cipta atas Batik di Kota Serang Provinsi Banten”, Ajudikasi: Jurnal Ilmu Hukum, Volume 3 Nomor 2, Desember 2019, hlm. 191 
pencipta dan terus berlangsung selama 70 (tujuh puluh) tahun setelah pencipta meninggal dunia, dan hal ini terhitung mulai dari tanggal 1 Januari di tahun berikutnya. Apabila pemegang hak cipta 2 (dua) orang atau lebih maka perlindungan hak cipta berlaku semasa hidup pencipta, setelah pencipta yang meninggal dunia paling akhir maka ciptaannya akan mendapat perlindungan hak cipta selama 70 (tujuh puluh) tahun sesudahnya, terhitung mulai tanggal 1 Januari di tahun berikutnya. Apabila hak cipta atas ciptaannya tersebut dipegang oleh badan hukum, maka berlaku selama 50 (lima puluh) tahun sejak pertama kali dilakukan pengumuman hak cipta. Selama jangka waktu perlindungan tersebut, pemegang hak cipta memiliki hak eksklusif untuk melarang pihak lain mengumumkan dan memperbanyak ciptaannya, atau memberi izin kepada orang lain untuk melakukan pengumuman dan untuk memperbanyak ciptaan tanpa mengurangi pembatasan-pembatasan menurut peraturan perundang-undangan yang berlaku. ${ }^{20}$

Untuk pendaftaran dari hak cipta diselenggarakan oleh Direktorat Jenderal Hak Kekayaan Intelektual (Ditjen HKI), yang saat ini berada di bawah kementerian Hukum dan HAM. Permohonan pendaftaran hak cipta diajukan dengan berkas seperti surat rangkap dua, yang ditulis dalam bahasa Indonesia di atas kertas polio berganda. Dalam surat permohonan tersebut memuat:

1. Nama, kewarganegaraan, dan alamat pencipta;

2. Nama, kewarganegaraan, dan alamat pemegang hak cipta;

3. Nama, kewarganegaraan, dan alamat kuasa;

4. Jenis dan judul ciptaan;

5. Tanggal dan tempat ciptaan diumumkan untuk pertama kali;

6. Uraian ciptaan rangkap tiga.

Ditjen HKI akan memberikan keputusan paling lama 9 bulan terhitung sejak tanggal diterimanya permohonan pendaftaran hak cipta secara lengkap. Pencipta atau pemilik hak cipta dapat mendaftarkan langsung ciptaannya maupun melalui kuasa dari pemegang hak cipta. Kuasa dari pemegang hak cipta yang dimaksud adalah konsultan Hak Kekayaan Intelektual (HKI). Konsultan HKI adalah orang yang memiliki keahlian di bidang HKI dan secara khusus memberikan jasa di bidang pengajuan dan pengurusan permohonan pendaftaran di bidang HKI yang dikelola oleh Ditjen Hak Kekayaan Intelektual dan terdaftar sebagai konsultan HKI di Ditjen HKI. Adapun tugas dari konsultan HKI adalah mewakili, mendampingi dan membantu kepentingan pihak pengguna jasa untuk mengurus permohonan HKI kepada Ditjen HKI dengan disertai surat kuasa, dan memperoleh imbalan atas jasa.

\footnotetext{
${ }^{20}$ Mastur dan Siti Khotimah, "Perlindungan Hak Cipta Motif Batik Lasem Dalam Undang-Undang Nomor 28 Tahun 2014”, Jurnal Ilmiah Ilmu Hukum QISTIE, Volume 12 Nomor 2, November 2019, hlm. 158
} 
Mekanisme pengaturan perlindungan telah dimuat dalam ketentuan UndangUndang Nomor 28 Tahun 2014 tentang Hak Cipta. Bentuk perlindungannya diatur mengenai sanksi-sanksi pidana bagi pelaku pelanggaran yang digolongkan menjadi dua macam, yaitu: pelaku utama adalah perseorangan maupun badan hukum yang dengan sengaja melanggar hak cipta atau melanggar larangan undang-undang, termasuk pelaku utama ini adalah penerbit, pembajak, penjiplak, dan pencetak. Serta, pelaku pembantu adalah pihak-pihak yang menyiarkan, memamerkan atau menjual kepada umum setiap ciptaan yang diketahuinya melanggar hak cipta atau melanggar larangan Undang-Undang Hak Cipta. Yang termasuk ke dalam pelaku pembantu ini adalah penyiar, penyelenggara pameran, penjual, dan pengedar yang menyewakan setiap ciptaan hasil kejahatan/pelanggaran hak cipta atau larangan yang diatur oleh undang- undang.

Dalam rangka penyelesaian hukum terhadap pelanggaran hak cipta, UndangUndang Nomor 28 Tahun 2014 tentang Hak Cipta, memberikan pilihan dalam penyeleseian hukum bagi pencipta atau pemegang hak cipta yang haknya dilanggar oleh pihak lain. Berikut adalah mekanisme penyelesaian hukum bagi pencipta yang ingin mempertahankan haknya: ${ }^{21}$

a. Gugatan Perdata, mekanisme ini diatur di dalam Pasal 99 Undang-Undang Nomor 28 Tahun 2014 tentang Hak Cipta. Pemegang hak cipta berhak mengajukan gugatan ganti rugi kepada pengadilan niaga atas pelanggaran hak ciptaannya dan meminta penyitaan terhadap benda yang diumumkan atau hasil pembajakan ciptaan tersebut. Pemegang hak cipta juga berhak memohon kepada pengadilan niaga agar memerintahkan penyerahan seluruh atau sebagian penghasilan yang diperoleh dari penyelenggaraan ceramah, pertemuan ilmiah, pertunjukan atau pameran karya yang merupakan hasil dari pelanggaran hak cipta. Sebelum menjatuhkan putusan akhir dan untuk mencegah kerugian yang lebih besar pada pihak yang haknya dilanggar hakim dapat memerintahkan pelanggar untuk menghentikan kegiatan pengumuman dan/atau perbanyak ciptaan barang yang merupakan hasil dari pelanggaran hak cipta.

b. Tuntutan Pidana, ketentuan pidana bagi pelanggaran hak cipta diatur di dalam Pasal 112-118 Undang-Undang Nomor 28 Tahun 2014 tentang Hak Cipta, pengajuan gugatan perdata tetap bisa dilakukan bersama tuntutan pidana. Proses perdata tidak menggugurkan hak negara untuk melakukan tuntutan pidana, sebelum dilakukannya tuntutan pidana pada Pasal 95 Undang-Undang

${ }^{21}$ Abdul Atsar, Mengenal Lebih Dekat Hukum Hak Kekayaan Intelektual, (Yogyakarta: deepublish, 2019), hlm.42-43 
Nomor 28 Tahun 2014 tentang Hak Cipta mengharuskan terlebih dahulu untuk dilakukannya mediasi sebelum tuntutan pidana dilakukan.

c. Penyelesaian Sengketa melalui Alternatif Penyelesaian Sengketa atau Alternatif Dispute Resulation (ADR) dalam bentuk negosiasi, mediasi, konsoliasi, dan cara-cara lain yang dipilih oleh para pihak sesuai dengan ketentuan undang-undang yang berlaku.

Terkait dengan masalah penyelesaian sengketa pada Undang-Undang Nomor 28 Tahun 2014 tentang Hak Cipta pada dasarnya telah mengatur baik ketentuan pidana maupun ketentuan perdata di dalamnya. Namun, untuk penggunaan hukum pidana tetap dijadikan sebagai upaya terakhir (ultimum remedium) setelah upaya lain misalnya mediasi, arbitrase dirasa kurang memuaskan.

\section{KESIMPULAN}

Berdasarkan hasil pembahasan dan analisis yang telah diuraikan disimpulkan bahwa seni batik khas Kabupaten Karawang dimulai pada tahun 1860 oleh seseorang bernama Tan Tjeng Kwat, seiring berjalannya waktu pada tahun $2008 \mathrm{Ibu} \mathrm{Hj}$ Istiqomah kembali menghidupkan batik Khas Kabupaten Karawang, terhitung sudah 25 motif batik yang dihasilkan oleh Ibu $\mathrm{Hj}$. Istiqomah diantaranya adalah motif Citarum, Motif Pare Sagedeng, motif Padi, dan sebagainya. Perlindungan hukum motif batik khas Kabupaten Karawang menurut Undang-Undang Nomor 28 Tahun 2014 tentang Hak Cipta sudah dilindungi, perlindungannya sesuai dengan Pasal 1 ayat (1) tentang hak cipta, Pasal 1 ayat (2) tentang pencipta, dan Pasal 1 ayat (3) tentang ciptaan. Motif batik khas Kabupaten Karawang hasil kreasi dan inovasi dari pengrajin batik yang juga dilindungi menurut Pasal 40 ayat (1) huruf j Undang-undang Nomor 28 Tahun 2014 tentang Hak Cipta. Karya tersebut dilindungi karena mempunyai nilai seni, baik dalam kaitannya dengan gambar, corak, maupun komposisi warna. Selain itu, motif batik khas Kabupaten Karawang telah mendapat perlindungan hukum di dalam hukum positif di Indonesia.

Selain itu, penulis mempunyai saran yang diharapkan kedepannya menjadi suatu awalan untuk perubahan yang lebih baik, yaitu sebagai berikut:

a. Penulis mengharapkan kesadaran dari berbagai pihak untuk menjaga dan melestarikan batik khas Kabupaten Karawang.

b. Penulis juga mengharapkan agar beberapa motif batik khas Kabupaten Karawang untuk didaftarkan hak ciptanya. Karena hal tersebut akan menguntungkan pencipta dan pemegang hak cipta, serta agar tidak terjadinya pelanggaran terhadap hak cipta. 


\section{DAFTAR PUSTAKA}

Atsar, Abdul. Mengenal Lebih Dekat Hukum Hak Kekayaan Intelektual. Yogyakarta: deepublish. 2019.

Hasan, Iqbal. Metode Penelitian Hukum dan Aplikasinya. Bandung: Remaja. 2002.

Hidayah, Khorul. Hukum HKI: Hak Kekayaan Intelektual. Malang: Setara Press. 2017.

Khairandy, Ridwan. Pengantar Hukum Dagang. Yogyakarta: UII Press. 2006

Linsey, Tim. et,all. Hak Kekayaan Intelektual: Suatu Pengantar. Bandung: PT. Alumni. 2013.

Soekanto, Soerjono. Pengantar Penelitian Hukum. Jakarta: Universitas Indonesia. 2006.

\section{Jurnal}

Andhini, Alycia Sandra Dina, and Ridwan Arifin. "Analisis Perlindungan Hukum Terhadap Tindak Kekerasan Pada Anak Di Indonesia.” Ajudikasi : Jurnal Ilmu Hukum Vol. 3, No. 1 (2019): 41-52. https://doi.org/10.30656/ajudikasi.v3i1.992.

Fuqoha, Fuqoha, Indrianti Azhar Firdausi, and Arga Eka Sanjaya. "Perlindungan Hukum Terhadap Intervensi Pemberitaan Dalam Kerangka Kemerdekaan Pers Nasional.” Ajudikasi: Jurnal Ilmu Hukum Vol. 3, $\quad$ No. 1 (2019): 75. https://doi.org/10.30656/ajudikasi.v3i1.1436.

Iskandar dan Eny Kustiyah. "Batik Sebagai Identitas Kultural Bangsa Indonesia Di Era Globalisasi”. Jurnal Gema. Volume 52. Agustus 2016-Januari 2017.

Kusumaningtyas, Rindia Fanny. "Perlindungan Hak Cipta Atas Motif Batik Sebagai Warisan Budaya Bangsa". Jurnal Online. Januari 2014.

Mastur dan Siti Khotimah. "Perlindungan Hak Cipta Motif Batik Lasem Dalam UndangUndang Nomor 28 Tahun 2014”. Jurnal Ilmiah Ilmu Hukum QISTIE. Volume 12 Nomor 2. November 2019.

Rahayu, Devi. "Perlindungan Hukum Terhadap Hak Cipta Motif Batik Tanjungbumi Madura". Jurnal Mimbar Hukum. Volume 23 Nomor 1. Februari 2011.

Sulasno dan Mia Mukaromah. "Perlindungan Hukum Terhadap Hak Cipta atas Batik di Kota Serang Provinsi Banten”. Ajudikasi: Jurnal Ilmu Hukum. Volume 3 Nomor 2. Desember 2019.

Trixie, Alicia Amaris. "Filosofi Motif Batik Identitas Bangsa Indonesia". Jurnal Folio. Volume 1 Nomor 1. Februari 2020.

\section{Peraturan Perundang-undangan}

Indonesia, Undang-Undang Nomor 28 Tahun 2014 tentang Hak Cipta

\section{Naskah Internet/Website}

Dedi Satria, "Batik Taza Khas Karawang, Kedepankan Motif Kearifan Lokal”, dalam Naskah Online/Website (Oktober 2019), https://www.pasundanekspress. co/jabar/karawang/batik-taza-khas-karawang-kedepankan- motif-kearifan-lokal/ (diakses pada tanggal 15 November 2020 pukul 15.00 WIB). 
AJUDIKASI : Jurnal Ilmu Hukum, Volume 4 Nomor 2, Desember 2020. Hlm 125-140 P-ISSN 2613-9995 \& E-ISSN 2614-0179

Sabrina Santi, "Sejarah Batik Karawang", dalam Naskah Online/Website (April, 2018), https://infobatik.id/sejarah-batik-karawang/. (diakses pada tanggal 15 November 2020, pukul 09. 13 WIB). 